\title{
Alternativas quirúrgicas de la enfermedad metastásica
}

Simposium de la S.E.O.Q.

IX Congreso Nacional de la S.E.O.M.

Tenerife, 2003.

En junio de 2003, en el contexto del IX Congreso Nacional de la S.E.O.M., la Sociedad Española de Oncología Quirúrgica organizó una mesa redonda para la revisión actualizada del papel de la cirugía en el tratamiento de la enfermedad diseminada. Se introdujo con un breve análisis global de la situación, resultando evidente que, aunque es posible el tratamiento quirúrgico de las metástasis en cualquier localización en el organismo, la cirugía desempeña un papel esencial fundamentalmente en el tratamiento de la enfermedad metastásica localizada en hígado, pulmón y peritoneo. En consecuencia se desarrollaron ponencias para analizar la problemática inherente a cada una de dichas localizaciones. Dado el interés actual por los tratamientos adyuvantes, se incluyó una ponencia para evaluar la contribución del tratamiento adyuvante al tratamiento quirúrgico de las metástasis.

\begin{abstract}
Surgical alternatives to metastatic disease
In June 2003, in the context of the IX National Congress of the Spanish Society of Medical Oncology (S.E.O.Q.), the Spanish Society of Surgical Oncology (S.E.O.Q.) organized a round table on the up-dated review of the role of surgery in the treatment of disseminated disease. It began with a brief global analysis of the situation, it being clear that, although surgical treatment of the metastases is possible in any site of the body, surgery plays an essential role fundamentally in the treatment of metastatic disease located in the liver, lung and peritoneum. Consequently, speeches were developed to analyze the problem inherent to each one of these sites. Given the present interest for the adjuvant treatments, a speech was included to evaluate the contribution of the adjuvant treatment to surgical treatment of the metastases.
\end{abstract}

\section{Alternativas quirúrgicas de la enfermedad metastásica. Consideraciones generales}

\author{
Manuel García de Polavieja Carrasco \\ Servicio de Cirugía General y Aparato Digestivo I. Hospital Universitario Marqués de Valdecilla. Santander. España.
}

En la excelente monografía titulada "Cirugía Oncológica", el doctor Díe Goyanes define este concepto y delimita su campo de acción, analizando los diversos tipos de cirugía oncológica en función de las distintas aplicaciones e indicaciones que plantea el tratamiento quirúrgico de la enfermedad cancerosa (tabla 1) ${ }^{1}$. Sin embargo, la cirugía constituye un método de control locorregional del cáncer, por lo que cabría considerar que no tiene lugar en el tratamiento con pretensión curativa de la enfermedad diseminada, quedando -teóricamente- reservada su contribución para otras finalidades, como podría ser la de diagnosticar o confirmar el estadio diseminado de la enfermedad, su empleo como procedimiento de ayuda o de soporte en el tratamiento de la enfermedad diseminada (reservorios vasculares, ostomías, etc.), o la paliación, cuando las características del caso lo requieran.

No obstante, disponemos hace ya tiempo de evidencia histórica del buen resultado con el tratamiento quirúrgico de las metástasis, habiéndose comunicado su tratamiento en múltiples localizaciones, incluyendo la afectación de partes blandas, hueso, hígado, pulmón, sistema nervioso central, mediastino, páncreas, estómago, o cavidad peritoneal. Por otra parte, hemos asistido a un desarrollo significativo del conocimiento de la biología tumoral en general, y en particular del 